\begin{tabular}{|l|l|l|}
\hline \multicolumn{2}{|c|}{ PublisherInfo } \\
\hline \hline PublisherName & $:$ & BioMed Central \\
\hline \hline PublisherLocation & $:$ & London \\
\hline \hline PublisherImprintName & $:$ & BioMed Central \\
\hline \hline
\end{tabular}

\title{
Cerebral oxygen saturation measured by near-infrared spectroscopy and jugular oxygen saturation
}

\begin{tabular}{|l|l|l||}
\hline \multicolumn{2}{|c||}{ ArticleInfo } \\
\hline \hline ArticleID & $:$ & 4106 \\
\hline \hline ArticleDOI & $:$ & $10.1186 /$ ccf-1999-2361 \\
\hline \hline ArticleCitationID & $:$ & 2361 \\
\hline \hline ArticleSequenceNumber & $:$ & 43 \\
\hline \hline ArticleCategory & $:$ & Paper Report \\
\hline \hline ArticleFirstPage & $:$ & 1 \\
\hline \hline ArticleLastPage & $:$ & 4 \\
\hline \hline & & RegistrationDate : 1999-12-7 \\
\hline ArticleHistory & $:$ & OnlineDate \\
\hline \hline ArticleCopyright & $:$ & Current Science Ltd1999-12-7 \\
\hline \hline ArticleGrants & $:$ & \\
\hline \hline ArticleContext & $:$ & 130541111 \\
\hline \hline
\end{tabular}




\section{Keywords}

Brain, haemodynamics, spectroscopy, transcranial doppler

\section{Comments}

This paper examines an important question of whether extrapolation of data from normal subjects to those with critical illness, is valid. The answer would seem to be that in this case, it is not. In addition to errors with equipment algorithms or technical failures, the dramatically altered physiology in acute closed head injury would appear to make $\mathrm{SCO}_{2}$ an invalid monitor of cerebral oxygenation.

\section{Introduction}

Several studies have shown that cerebral oxygen saturation $\left(\mathrm{SCO}_{2}\right)$, measured by near infrared spectroscopy (NIRS), responds rapidly to changes in cerebral perfusion in normal subjects. The method has not been studied in more complex situations such as in neuro ICU. In this setting, changes in cerebral blood flow and vascular tone may alter the arteriovenous (AV) distribution of blood in the scalp and extracerebral tissues, leading to inaccuracies.

\section{Aims}

To study the relationship between NIRS $\mathrm{SCO}_{2}$ and jugular venous oxygen saturation $\left(\mathrm{SjvO}_{2}\right)$ during changes in arterial carbon dioxide tension and blood pressure, in adults with head trauma.

\section{Methods}

In total, nine patients with severe closed head injury and diffuse brain swelling or multifocal contusions were studied in the first 10 days following their injury. All patients were mechanically ventilated and sedated, those who were hypotension (MAP $<70 \mathrm{~mm} \mathrm{Hg}$ ) prior to the start of the study 
received a norepinephrine infusion. A jugular catheter was inserted into the side of the dominant jugular vein. $\mathrm{SCO}_{2}$ was recorded using NIRS and middle cerebral artery blood velocity (MACv) was measured using pulsed Doppler. $\mathrm{PaCO}_{2}$ was then altered to a level of moderate hypocapnia $\left(\mathrm{PaCO}_{2} 30-35\right)$, intense hypercapnia $\left(\mathrm{PaCO}_{2} 20-25 \mathrm{~mm} \mathrm{Hg}\right)$ or moderate hypercapnia. Cerebral vascular resistance was calculated as cerebral perfusion pressure (CPP) divided by MCAv and was measured before and after the $\mathrm{CO}_{2}$ changes. A response to changes in MAP was then examined by either starting or stopping a norepinephrine infusion depending on whether the patient was at the upper or lower limit of the cerebral autoregulation curve.

\section{Results}

Data were plotted according to the method of Bland and Altmann. The plots showed decreasing differences between changes in $\mathrm{SCO}_{2}$ and $\mathrm{SvjO}_{2}$ when the mean of this difference increased, suggesting that the bias was not random. Regression analysis showed that both tests were different in terms of magnitude and also that the relationship between changes in $\mathrm{SCO}_{2}$ and $\mathrm{SvjO}_{2}$ during $\mathrm{CO}_{2}$ and pressure were opposite.

\section{Discussion}

$\mathrm{SCO}_{2}$, assessed by NIRS, does not adequately reflect changes in $\mathrm{SvjO}_{2}$ in patients with severe head injury. The changes in extracerebral tissues on $\mathrm{SCO}_{2}$ is critical. The use of norepinephrine, in cases with impaired autoregulation, will lead to increased cerebral blood flow in proportion to MAP, and decreased blood flow to the extracerebral tissues. Conversely increased $\mathrm{CO}_{2}$ leads to global increases in blood flow in both regions. These findings may not be apparent in studies looking at decreases in oxygen saturation which would be the same in all compartments (eg hypoxic challenges). In addition the physiology of these patients is complex, with regional variations in cerebral blood flow and areas of ischaemia and hyperaemia.

\section{References}

1. Minassian AT, Poirer N, Pierrot M, Menei P, Granry JC, Ursino M, Beydon L: Correlation between cerebral oxygen saturation measured by near-infrared spectroscopy and jugular oxygen saturation in patients with severe closed head injury. Anesthesiology. 1999, 91: 985-990. 